\title{
Comparison of different levels of positive expiratory pressure on chest wall volumes in healthy children and patients with fibrosis
}

Comparação de diferentes niveis de pressão expiratória positiva em volumes de parede torácica em crianças saudáveis e pacientes com fibrose

Comparación de los diferentes niveles de la presión espiratoria positiva en los volumenes de la pared torácica en niños saludables y pacientes con fibrosis

Silvia Angélica Brilhante', Rêcio Bento Florêncio², Lucien Peroni Gualdi³, Vanessa Regiane Resqueti ${ }^{4}$, Andrea Aliverti ${ }^{5}$, Armele de Fátima Dornelas Andrade ${ }^{6}$, Guilherme Augusto de Freitas Fregonezi ${ }^{7}$

\begin{abstract}
Positive Expiratory Pressure (PEP) improves lung function, however, PEP-induced changes are not fully established. The aim of this study was to assess the acute effects of different PEP levels on chest wall volumes and the breathing pattern in children with Cystic Fibrosis (CF). Anthropometric data, lung function values, and respiratory muscle strength were collected. Chest wall volumes were assessed by Optoelectronic plethysmography at rest and during the use of different PEP levels ( 10 and $20 \mathrm{~cm} \mathrm{H2O}$ ), randomly chosen. Eight subjects with CF (5M, 11.5 \pm 3.2 years, $32 \pm 9.5$ kilograms) and seven control subjects (4M, $10.7 \pm 1.5$ years, $38.2 \pm 7.8$ kilograms) were recruited. The CF group showed significantly lower FEF values $25-75 \%$ (CF: $1.8 \pm 0.8$ vs. CG: $2.3 \pm 0.6$ ) and $F E V 1 / F V C$ ratio (CF: $0.8 \pm 0.1$ vs. CG: $1 \pm 0.1$ ) compared with the control group $(p<0.05)$. Different PEP levels increased the usual volume in chest wall and its compartments in both groups; however, this volume was significantly higher in the control group compared
\end{abstract}

with the CF group during PEP20 (CW: $0.77 \pm 0.25 \mathrm{~L}$ vs. $0.44 \pm 0.16$ L; RCp: $0.3 \pm 0.13$ L vs. $0.18 \pm 0.1$ L; RCa: $0.21 \pm 0.1$ L vs. $0.12 \pm 0.1 \mathrm{~L} ; \mathrm{AB}$ : $0.25 \pm 0.1 \mathrm{~L}$ vs. $0.15 \pm 0.1 \mathrm{~L} ; p<0.05$ for all variables). Minute ventilation was significantly higher during PEP compared with breathing at rest in both groups $(p<0.005)$. End-expiratory volume was also higher during PEP compared with breathing at rest for chest wall and pulmonary rib cage in both groups $(p<0.05)$. Different PEP levels may increase chest wall volumes in CF patients.

Keywords | Cystic Fibrosis; Respiratory Therapy; Respiratory System; Thoracic Wall.

RESUMO | Pressão Expiratória Positiva (PEwP) melhora a função pulmonar, entretanto, as mudanças induzidas pela PEP não estão totalmente estabelecidas. $O$ objetivo do estudo foi avaliar os efeitos agudos de diferentes intensidades de PEP nos volumes da parede torácica (PT) e padrão respiratório em crianças com Fibrose Cística (FC). Dados antropométricos,

This study was partially presented in the XIV European Respiratory Annual Congress - 2011 - Amsterdam.

'Master's degree and Reseacher in the Laboratório de Desempenho PneumoCardioVascular \& Músculos Respiratórios of the

Physiotherapy Department at the Universidade Federal do Rio Grande do Norte (UFRN) - Natal (RN), Brazil.

${ }^{2}$ PhD Student and Reseacher in the Laboratório de Desempenho PneumoCardioVascular \& Músculos Respiratórios of the Physiotherapy Department at the Fisioterapia da Universidade Federal do Rio Grande do Norte (UFRN) - Natal (RN), Brazil. ${ }^{3}$ Professor of the Faculdade de Ciências da Saúde do Trairi at the Universidade Federal do Rio Grande do Norte (UFRN) - Natal (RN), Brazil.

${ }^{4}$ Coordinator and Professor of the Laboratório de Desempenho PneumoCardioVascular \& Músculos Respiratórios of the Physiotherapy Department at the Universidade Federal do Rio Grande do Norte (UFRN) - Natal (RN), Brazil. Professor of the PneumoCardioVascular Lab do Hospital Universitário Onofre Lopes at the Empresa Brasileira de Serviços Hospitalares (EBSERH) of the Universidade Federal do Rio Grande do Norte Norte (UFRN) - Natal (RN), Brazil.

${ }^{5}$ Professor of the Dipartimento di Elettronica, Informazione e Bioingegneria - Politecnico di Milano, Milano, Itália.

${ }^{6}$ Professor of the Physiotherapy Department at the Universidade Federal de Pernambuco (UFPE) - Recife (PE), Brazil. ${ }^{7}$ Professor of the Laboratório de Desempenho PneumoCardioVascular \& Músculos Respiratórios of the Physiotherapy Department at the Universidade Federal do Rio Grande do Norte (UFRN) - Natal (RN), Brazil. Coordinator and Professor of the PneumoCardioVascular Lab do Hospital Universitário Onofre Lopes at the Empresa Brasileira de Serviços Hospitalares (EBSERH) of the Universidade Federal do Rio Grande do Norte Norte (UFRN) - Natal (RN), Brazil. 
função pulmonar e força da musculatura respiratória. Os volumes da PT foram avaliados através da Pletismografia Optoeletrônica (POE) em repouso e durante o uso de diferentes intensidades de PEP (10 e $20 \mathrm{~cm} \mathrm{H2O}$ ). Foram recrutados 8 sujeitos com FC ( $5 \mathrm{H} ; 11,5 \pm 3,2$ anos; $32 \pm$ 9,5 kg) e 7 sujeitos (4H; 10,7 \pm 1,5 anos; 38,2 \pm 7,8 kg). Grupo FC mostrou valores significativamente menores para FEF 25-75\% (FC: 1,8 $\pm 0,8$ vs. GC: $2,3 \pm 0,6$ ) e relação VEF1/CVF (FC: 0,8 $\pm 0,1$ vs. GC: $1 \pm 0,1)$ comparado ao grupo controle $(p>0,05)$. Diferentes intensidades de PEP levaram a um aumento do volume corrente da PT e seus compartimentos em ambos os grupos, entretanto, este volume aumentou de forma significativa no grupo controle quando comparado ao grupo FC durante PEP20 (CW: 0,77 \pm 0,25 L vs. 0,44 \pm 0,16 L; RCp: 0,3 $\pm 0,13$ L vs. 0,18 $\pm 0,1$ L; RCa: 0,21 $\pm 0,1$ L vs. 0,12 $\pm 0,1$ L; AB: 0,25 $\pm 0,1 \mathrm{~L}$ vs. 0,15 $\pm 0,1 \mathrm{~L} ; p>0,05$ para todas as variáveis). A ventilação minuto aumentou de forma significativa durante a PEP em comparação a respiração em repouso para ambos os grupos ( $p>0,005)$. Volume expiratório final também foi maior durante a PEP em comparação a respiração em repouso para PT e caixa torácica pulmonar em ambos os grupos $(p>0,05)$. Diferentes intensidades de PEP podem induzir aumentos nos volumes da parede torácica em pacientes com FC.

Descritores I Fibrose Cística; Terapia Respiratória Sistema Respiratório; Parede Torácica.

RESUMEN | La Presión Espiratoria Positiva (PEP) mejora la función pulmonar, mientras tanto, los cambios inducidos por la PEP no están totalmente establecidos. El objetivo del estudio fue evaluar los efectos agudos de distintas intensidades de PEP en los volúmenes de la pared torácica (PT) y patrón respiratorio en niños con Fibrosis Cística (FC). Datos antropométricos, función pulmonar y fuerza de la musculatura respiratoria. Los volúmenes de la PT fueron evaluados a través de la Pletismografía Optoelectrónica (POE) en reposo y durante el uso de distintas intensidades de PEP (10 y $20 \mathrm{~cm} \mathrm{H2O}$ ). Fueron reclutados 8 sujetos con FC ( $5 \mathrm{H}$; 11,5 \pm 3,2 años; $32 \pm 9,5 \mathrm{~kg})$ y 7 sujetos (4H; 10,7 \pm 1,5 años; 38,2 \pm 7,8 kg). Grupo FC mostró valores significativamente menores para FEF 25-75\% (FC: 1,8 \pm 0,8 vs. GC: $2,3 \pm 0,6$ ) y relación VEF1/CVF (FC: 0,8 $\pm 0,1$ vs. GC: $1 \pm 0,1$ ) comparado al grupo control $(p>0,05)$. Distintas intensidades de PEP conllevaron a un incremento del volumen corriente de la PT y sus compartimentos en ambos los grupos, mientras tanto, este volumen incrementó de manera significativa en el grupo control cuando comparado al grupo FC durante PEP20 (CW: 0,77 $\pm 0,25 \mathrm{~L}$ vs. $0,44 \pm 0,16$ L; RCp: $0,3 \pm 0,13$ L vs. 0,18 $\pm 0,1$ L; RCa: 0,21 $\pm 0,1 \mathrm{~L}$ vs. $0,12 \pm 0,1 \mathrm{~L} ; A B: 0,25 \pm 0,1 \mathrm{~L}$ vs. 0,15 $\pm 0,1 \mathrm{~L} ; \mathrm{p}>0,05$ para todas las variables). La ventilación minuto incrementó de manera significativa durante la PEP en comparación a la respiración en reposo para ambos grupos $(p>0,005)$. El volumen espiratorio final también fue más grande durante la PEP en comparación a la respiración en reposo para PT y la caja torácica pulmonar en ambos los grupos ( $p>0,05)$. Las distintas intensidades de PEP pueden inducir incrementos en los volúmenes de la pared torácica en pacientes con FC.

Palabras clave | Fibrosis Quística; Terapia Respiratoria; Sistema Respiratorio; Pared Torácica.

\section{INTRODUCTION}

Cystic Fibrosis (CF) is a multi-system, autosomal recessive genetic disease characterized by chromosomal alteration that leads to ionic imbalance, promoting changes in exocrine glands secretion and resulting in abnormal functioning of several organs and systems ${ }^{1}$. CF patients show lung disorders such as mucosal secretion dehydration and viscosity increase, which lead to the obstruction of the small airways and triggering of a chronic inflammatory process ${ }^{2}$. Several respiratory complications can occur in $\mathrm{CF}$ patients as bronchiolitis, bronchitis, atelectasis, bronchiectasis, pneumothorax, hemoptysis, recurrent pneumonia, cor pulmonale, and respiratory failure ${ }^{3}$. Therefore, due to the pathophysiological process of $\mathrm{CF}$, these patients require daily respiratory therapy, aiming to improve lung ventilation and mucociliary clearance through secretion removal ${ }^{4,5}$.
Airways clearance techniques are considered of great clinical benefit to reduce lung complications and their prescription is relevant to the clinical course of the disease in these patients ${ }^{6}$. Moreover, airway clearance techniques facilitate bronchial hygiene and, consequently, improve lung function, which is considered essential for optimizing respiratory status and reducing the progression of lung disease ${ }^{7}$. Selfadministered therapies as Positive Expiratory Pressure $(\mathrm{PEP})$ are being used to promote greater independence to the patient ${ }^{8}$. Studies have shown that the use of PEP induces important benefits in blood gases concentration, aerosol particles deposition, expectoration, airflow, and, consequently, lung function ${ }^{9,10}$. However, PEP-induced changes on lung volumes are not fully established due to muscular limitations and consequent respiratory muscles asynchronous activity that may be present in children with $\mathrm{CF}^{11}$. Besides lung disorders, children with $\mathrm{CF}$ frequently show paradoxical or asynchronous 
motion between chest wall and abdomen during breathing ${ }^{12-14}$. This alteration is related to disease severity, increased risk of respiratory failure, and poor prognosis in patients with obstructive disease ${ }^{15,16}$.

Therefore, the aim of this study was to compare the changes of different intensities of PEP on chest wall volumes and breathing pattern in children with $\mathrm{CF}$ and healthy controls. Chest wall volume analysis was performed by Optoelectronic Plethysmography (OEP), which can detect variations in motion and volume of the chest wall and its compartments during breathing, allowing the analysis and evaluation of these changes during rest and/or exercise ${ }^{17}$.

\section{METHODOLOGY}

\section{Subjects}

Subjects with CF diagnosis were recruited at the Cystic Fibrosis Multidisciplinary Clinic of a University Hospital. Age-matched healthy controls without previous history of cardiopulmonary disease were recruited in the community. Individuals of both genders, aged 7 years, able to perform acceptable evaluation exams, lung function, and respiratory muscle strength tests and with no postural disorders were included in the study. Subjects who presented disease exacerbation, such as hospitalization three weeks prior to data collection due to respiratory infection, used medication that could interfere in the exam results, such as short-term bronchodilator, and that did not complete all exams, quit or missed an appointment during the evaluation period were excluded from the study. This study was submitted and approved by the Research Ethics Committee of the University Hospital (number 497/10). All participants and their guardians were informed about the study and signed an Informed Consent form in accordance with the principles of the Helsinki declaration ${ }^{18}$.

\section{Study design}

This is a cross-sectional study performed in a single day at the Laboratory of PneumoCardioVascular and Respiratory Muscle Performance. Before sample collection, the study was explained to the individuals, who were then interviewed regarding their medical history and medication use. Anthropometric characteristics were assessed before data collection. Next, subjects underwent spirometry and respiratory muscle strength assessment. Lastly, chest wall volumes were assessed by Optoelectronic Plethysmography using two different intensities of PEP (10 and $20 \mathrm{~cm} \mathrm{H}_{2} \mathrm{O}$ ). PEP intensity order randomization was performed manually by using a brown paper envelope. Room temperature during data collection was set between 22 and $24^{\circ} \mathrm{C}$, with relative air humidity between 50 and $60 \%$.

\section{Anthropometric evaluation}

Weight and height were determined using an anthropometric scale (Welmy, Santa Bárbara D’Oeste, São Paulo, Brazil). The values obtained were used to calculate Body Mass Index (BMI) (weight (kg)/ height $^{2}(\mathrm{~m})$ ). Percentile values of BMI were used for anthropometric characterization according to the cutoff points recommended by the World Health Organization ${ }^{19}$.

\section{Spirometry}

The technical procedure, acceptability and reproducibility criteria, reference and interpretative values, as well as standardization and equipment followed the recommendations of the American Thoracic Society (ATS)/European Respiratory Society $(\mathrm{ERS})^{20}$. Reference forced expiratory volume in the first second $\left(\mathrm{FEV}_{1}\right)$, forced vital capacity (FVC), and $\mathrm{FEV}_{1}$ / FVC ratio were obtained by derivations from the preestablished equations ${ }^{21}$. All procedures were performed in seated position. A DATOSPIR ${ }^{\circledast} 120$ (Sibelmed, Barcelona, Spain) device, calibrated daily, was used.

\section{Respiratory muscle strength}

Respiratory muscle strength was assessed by maximal inspiratory pressure (MIP) and maximal expiratory pressure (MEP) using a MVD300 digital manometer (GlobalMed, Porto Alegre, Brazil). Measures were collected according to the recommendations of the American Thoracic Society/European Respiratory Society, using the reference values obtained for children $^{22,23}$. Briefly, MIP was measured following maximal inspiration from residual volume with nasal nostril closed, while MEP was obtained through maximal expiration from total lung capacity in seated 
position. A nozzle with a hole of approximately $1 \mathrm{mmwas}$ used to dissipate facial and oropharynx muscles pressure. Five to eight tests were performed until maximal values were reproducible.

\section{Assessment of chest wall volumes and PEP}

Optoelectronic pletysmography (OEP) $\left(\mathrm{OEP}^{\oplus}\right.$ system, BTS, Milan, Italy) was used to evaluate chest wall and its compartments (Pulmonary Rib Cage Rcp, Abdominal Rib Cage - Rca and Abdomen $\mathrm{Ab})$, volumes, and their variations during rest and different levels of PEP in both groups. All individuals were positioned in seated position on a backless bench and centralized in a system of six cameras previously calibrated according to the manufacturer's recommendations and previously published studies ${ }^{24-26}$. Subjects were requested to remain motionless breathing freely for 180 seconds. After quiet breathing (QB), chest wall volumes was evaluated using two different PEP intensities (10 and $20 \mathrm{~cm} \mathrm{H}_{2} \mathrm{O}$ ), randomly chosen, using the Threshold $\mathrm{PEP}^{\circledast}$ independent flow device (Health Scan Products Inc. Cedar Grove, USA) for the same period of QB (180 seconds). A minimal resting period of 20 minutes between different intensities of PEP was given to subjects. After the data was acquired the most stable period of 30 seconds of each period was analyzed. We considered the following variables for analysis: total tidal volume, percentage contribution of the different chest wall compartments ( $\mathrm{RCp}, \mathrm{RCa}$ and $\mathrm{AB})$ to tidal volume, minute ventilation, respiratory rate, inspiratory time $\left(\mathrm{T}_{\text {insp }}\right)$, expiratory time $\left(\mathrm{T}_{\text {exp }}\right)$, total respiratory cycle time, total and compartmental chest wall operating volumes, namely end-expiratory (EEV), and end-inspiratory (EIV) volumes. The changes in length of rib cage inspiratory muscle can be estimated by the relationship among Pulmonary Rib Cage volume variation and Inspiratory Time (VTrcp/Ti). The relationship can be used as a shortening velocity index of the rib cage inspiratory muscle ${ }^{25}$.

\section{Statistical analysis}

Shapiro-Wilk normality test was applied to the variables. Two-way analysis of variance (ANOVA) with Bonferroni post hoc was performed to verify the differences between the variables' means during quiet breathing and different PEP levels in the study groups. GraphPad Prism 5 software (GraphPad Software Inc.
San Diego, California, USA) was used for the analysis, with significance level set at $p>0.05$. The effect size was calculated using the $G^{*}$ Power software $\left(G^{*}\right.$ Power 3.1.9.2, Kiel, Germany).

\section{RESULTS}

Fourteen subjects with CF and 12 healthy individuals were enrolled. Six subjects from $\mathrm{CF}$ group were excluded: three due to disease exacerbation prior to sample recruitment, two due to irregularities and artifacts originated during data collection, and one due to study withdrawal). As for the healthy controls, five were excluded: three due to irregularities and artifacts originated during data collection and two due to study withdrawal.

The mean, standard deviation and standard deviation difference of respiratory rate were considered to calculate the effect size. We found a Cohen's d of 1.4 considering a $\alpha$ error probability of less than 0.05 ( $p>0.05$ ) with 0.70 of power. The result found indicated a large effect size ${ }^{27}$. Ideal sample size calculated to the study was eight subjects per group.

\section{Anthropometric characteristics}

No significant difference was found regarding anthropometric characteristics between CF group and controls for age, gender, weight, and height $(p>0.05)$. According to body mass index (BMI) percentile cutoff points, two subjects with $\mathrm{CF}(25 \%)$ showed values below those recommended for the age. In contrast, three (43\%) controls showed BMI values above those recommended for the age at the moment of sample collection. All anthropometric characteristics are shown in Table 1.

\section{Spirometry and maximal inspiratory/expiratory muscles pressures}

CF group showed significantly lower lung function values for $\mathrm{FEF}_{25-75 \%}$ and $\mathrm{FEV}_{1} / \mathrm{FVC}$ ratio when compared to the control group ( $p>0.05)$. Although $C F$ patients showed slightly lower mean values for MEP compared to controls, neither inspiratory nor expiratory maximal pressures were significantly different between the groups (Table 1). 
Table 1. Anthropometric characteristics and lung function values

\begin{tabular}{|c|c|c|c|}
\hline & $\begin{array}{l}\text { Cystic Fibrosis group } \\
(n=8)\end{array}$ & $\begin{array}{l}\text { Control group } \\
(n=7)\end{array}$ & p-value \\
\hline \multicolumn{4}{|c|}{ Anthropometric characteristics } \\
\hline Gender (M/F) & $5 / 3$ & $4 / 3$ & 1 \\
\hline Age (years) & $11.5 \pm 3.2$ & $10.7 \pm 1.5$ & 0.55 \\
\hline Weight (kg) & $32.1 \pm 9.6$ & $38.2 \pm 7.8$ & 0.20 \\
\hline Height (cm) & $140 \pm 12.8$ & $143 \pm 8.5$ & 0.48 \\
\hline \multicolumn{4}{|l|}{ Lung function } \\
\hline $\mathrm{FVC}(\mathrm{I} / \mathrm{s})$ & $1.9 \pm 0.5$ & $2 \pm 0.5$ & 0.60 \\
\hline FVC (\% pred) & $84.3 \pm 17.5$ & $82.8 \pm 11.9$ & 0.84 \\
\hline $\mathrm{FEV}_{1}(\mathrm{I} / \mathrm{s})$ & $1.5 \pm 0.4$ & $2 \pm 0.5$ & 0.06 \\
\hline $\mathrm{FEV}_{1}(\%$ pred) & $72.7 \pm 12.8$ & $84.6 \pm 14.4$ & 0.11 \\
\hline $\mathrm{FEF}_{25-75 \%}(\mathrm{I} / \mathrm{s})$ & $1.8 \pm 0.8$ & $2.3 \pm 0.6$ & 0.007 \\
\hline $\mathrm{FEV}_{1} / \mathrm{FVC}$ & $0.8 \pm 0.1$ & $1 \pm 0.1$ & 0.01 \\
\hline $\mathrm{FEV}_{1} / \mathrm{FVC}(\%)$ & $81.5 \pm 5.7$ & $96.9 \pm 13.5$ & 0.01 \\
\hline $\mathrm{MIP}\left(\mathrm{cm} \mathrm{H}_{2} \mathrm{O}\right)$ & $78.9 \pm 25.6$ & $85.3 \pm 21.4$ & 0.66 \\
\hline MIP (\% pred) & $85.5 \pm 23.5$ & $91.1 \pm 21.2$ & 0.39 \\
\hline $\operatorname{MEP}\left(\mathrm{cm} \mathrm{H}_{2} \mathrm{O}\right)$ & $85.1 \pm 25.9$ & $109 \pm 21.5$ & 0.05 \\
\hline MEP (\% pred) & $84.4 \pm 27.9$ & $110.3 \pm 24.57$ & 0.15 \\
\hline
\end{tabular}

*absolute values, values expressed in predicted percentage, p-value calculated using Fisher exact test for gender and unpaired t test for the other variables; FVC: Forced Vital Capacity; FEV: Forced Expiratory Volume in the first second; $\mathrm{FEF}_{25-75 \%}$ : Forced Expiratory Flow between 25 and $75 \%$ of the spirometric curve; $V$ EF $/$ /CVF\% ratio expressed in percentage; MIP: Maximal inspiratory pressure; MEP: Maximal expiratory pressure.

\section{Chest wall variations and breathing pattern during QB and PEP}

Intragroup analysis showed that tidal volume values in chest wall and its compartments were higher during the use of different PEP levels compared to quiet breathing in both groups ( $p>0.05)$. Regarding $\mathrm{PEP}_{10}$, no significant difference was found in intergroup analysis. However, total and compartmental tidal volumes were significantly higher in controls compared to $\mathrm{CF}$ patients during $\mathrm{PEP}_{20}$ (CW: $0.77 \pm 0.25 \mathrm{~L}$ vs. $0.44 \pm 0.16 \mathrm{~L} ; \mathrm{RCp}: 0.3 \pm 0.13 \mathrm{~L}$ vs. $0.18 \pm 0.1 \mathrm{~L} ; \mathrm{RCa}: 0.21 \pm 0.1 \mathrm{~L}$ vs. $0.12 \pm 0.1 \mathrm{~L} ; \mathrm{AB}$ : $0.25 \pm 0.1 \mathrm{~L}$ vs. $0.15 \pm 0.1 \mathrm{~L} ; \mathrm{p}>0.05$ ) (Figure 1 ).

Respiratory rate ( $\mathrm{RR}$, breaths/min) was significantly higher in the CF group $(36.3 \pm 7,33.8 \pm 14$ and $37.8 \pm 14.1$ during $\mathrm{QB}, \mathrm{PEP}_{10}$ and $\mathrm{PEP}_{20}$, respectively) compared to controls $(28.2 \pm 5.1,30.6 \pm 17.1$ and $24.3 \pm 14.6, \mathrm{p}>0.005)$. In both groups, minute ventilation $(\mathrm{MV}, \mathrm{L} / \mathrm{min})$ was significantly higher during $\mathrm{PEP}_{10}(15.6 \pm 7.6$ vs $19.5 \pm 9.2)$ and $\mathrm{PEP}_{20}(16.6 \pm 8.1$ vs $17.8 \pm 9.6)$ in $\mathrm{CF}$ patients and controls, when compared to quiet breathing (QB: $10.4 \pm 3.3$ vs. $8.1 \pm 1.2, \mathrm{p}>0.005)$. The increase in minute ventilation when using different intensities of PEP was obtained, however, by adopting different breathing patterns in the two groups (Figure 2A). While controls achieved increased ventilation with higher tidal volume (QB: $0.289 \pm 0.062 \mathrm{~L}$; $\mathrm{PEP}_{10}: 0.719 \pm 0.279 \mathrm{~L}$; and $\mathrm{PEP}_{20}: 0.755 \pm 0.259 \mathrm{~L}$ ) and lower respiratory rate during $\mathrm{PEP}_{20}, \mathrm{CF}$ children showed an inverse pattern with lower tidal volume (QB: $0.292 \pm 0.094 \mathrm{~L} ; \mathrm{PEP}_{10}: 0.492 \pm 0.169 \mathrm{~L}$; and $\mathrm{PEP}_{20}$ : $0.442 \pm 0.160 \mathrm{~L}$ ) and higher respiratory rate (Figure $2 \mathrm{~A}$ ).

Correspondingly, during $\mathrm{QB}, \mathrm{PEP}_{10}$ and $\mathrm{PEP}_{20}$, total respiratory cycle time (Ttot, seconds) was lower in $\mathrm{CF}$ patients compared to controls ( $p>0.02$, figure $2 \mathrm{~B})$. In $\mathrm{CF}$ patients, inspiratory time (Tinsp, seconds) was significantly lower than controls during $\mathrm{PEP}_{20}(0.74 \pm 0.2$ vs. $1.16 \pm 0.54, p>0.05)$ and did not change regarding what we observed during spontaneous quiet breathing at rest. Expiratory time (Texp) did not change significantly during PEP compared to $\mathrm{QB}$ in both groups. Although there was no significant difference, Texp tended to be higher in controls and lower in CF patients during PEP compared to $\mathrm{QB}$. The increase percentage of total and compartmental tidal volume regarding quiet breathing in resting conditions was slightly higher in controls than $\mathrm{CF}$ patients. During $\mathrm{PEP}_{10}$, the increase in $\mathrm{CW}, \mathrm{RCp}$, $\mathrm{RCa}$ and $\mathrm{AB}$ was $60 \%, 67 \%, 63 \%$, and $48 \%$ in controls and $40 \%, 52 \%, 52 \%$, and $13 \%$ in CF patients. During $\mathrm{PEP}_{20}$, the increase was $63 \%, 68 \%, 67 \%$, and $52 \%$ in controls and $34 \%, 40 \%, 45 \%$, and $18 \%$ in CF patients. The shortening velocity index of rib cage inspiratory muscle showed significant changes during $\mathrm{PEP}_{10}$ and $\mathrm{PEP}_{20}$ in the control group compared to baseline ( $p>0.05)$, without changes in intergroup analysis (Figure $2 \mathrm{C}$ ). 
Chest Wall

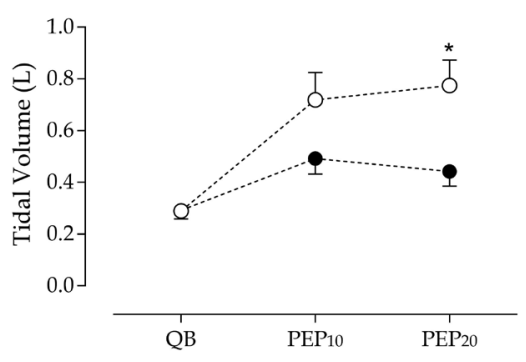

Abdominal Rib Cage

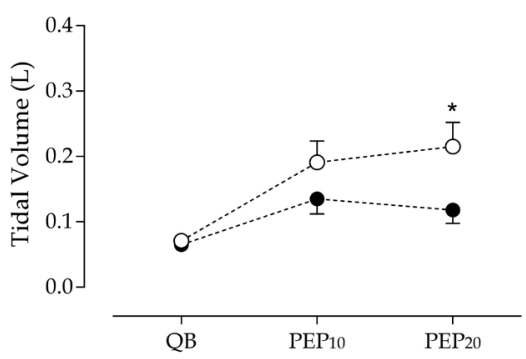

Pulmonary Rib Cage

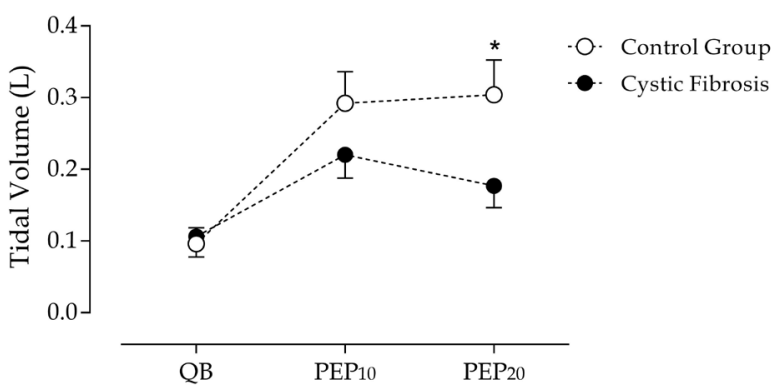

Abdomen



Figure 1. Volumes of chest wall and its compartments during quiet breathing and different levels of PEP in control group and CF Values represent mean \pm standard deviation. QB: quiet breathing; $P E P_{10}$ : positive expiratory pressure $10 \mathrm{~cm} \mathrm{H}_{2} \mathrm{O} ; \mathrm{PEP}_{20}$ : positive expiratory pressure $20 \mathrm{~cm} \mathrm{H}_{2} \mathrm{O}$. ${ }^{*} \mathrm{p}>0.05 \rrbracket \mathrm{PEP} 20 \mathrm{Vs}$. QB (two-way ANOVA).

A)

Minute Ventilation

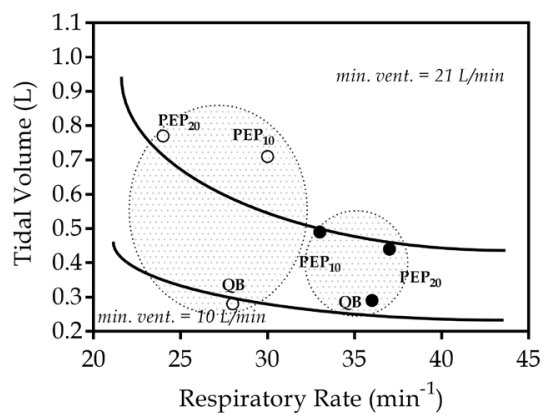

C)

Rib cage inspiratory muscle shorthening Velocity Index

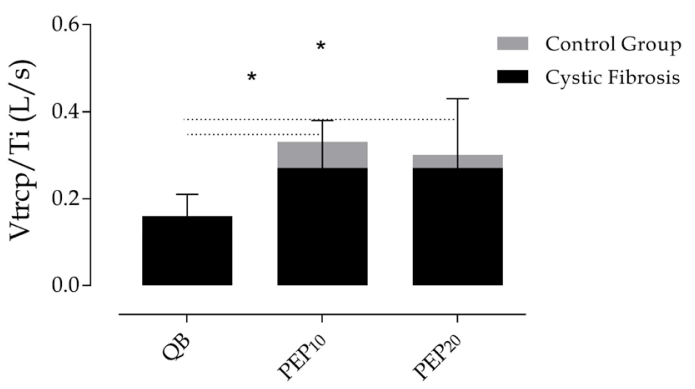

B)

$$
\text { Inspiratory Time }
$$

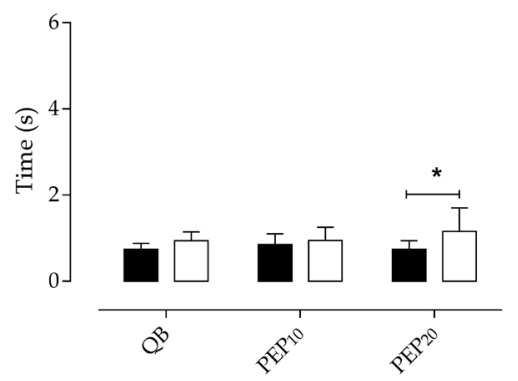

Expiratory Time

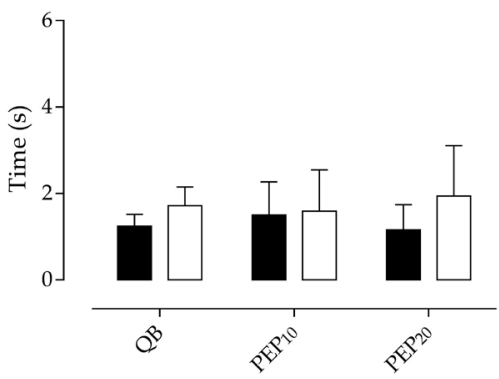

Total time

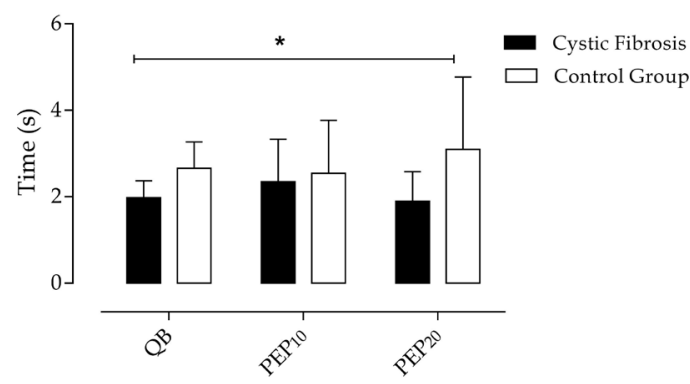

Figure 2. Breathing pattern and shortening velocity index of the rib cage inspiratory muscle of Values represent mean \pm standard deviation. QB: Quiet breathing; $\mathrm{PEP}_{10}$ : Positive expiratory pressure $10 \mathrm{~cm} \mathrm{H}_{2} \mathrm{O} ; \mathrm{PEP}_{20}$ : Positive expiratory pressure $20 \mathrm{~cm} \mathrm{H}_{2} \mathrm{O}$; Vtrcp/Ti: relation between pulmonary rib cage volume variation and inspiratory time. * $p>0.05$ (two-way ANOVA) 


\section{Total and compartmental chest wall operating volumes during different intensities of PEP}

End-expiratory volume (EEV) of total chest wall and pulmonary rib cage compartment significantly increased during the use of PEP (both intensities)
Chest Wall

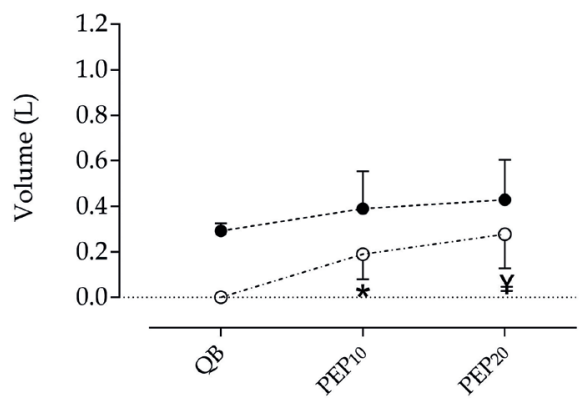

Abdominal Rib Cage



B)
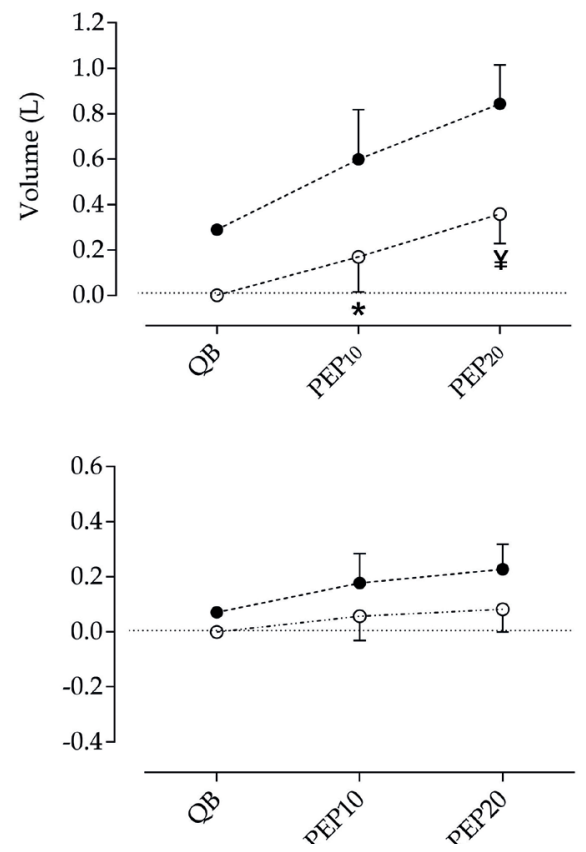

compared to resting conditions ( $\mathrm{p}>0.05)$ in both groups. Intergroup analysis did not show significant differences regarding EEV. End-inspiratory volume (EIV) was significantly increased in the rib cage pulmonary compartment during PEP compared to $\mathrm{QB}$ ( $\mathrm{p}>0.01$ ) (Figure 3).

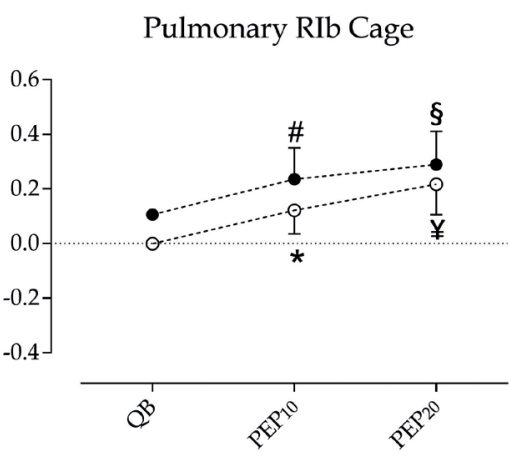

Abdomen
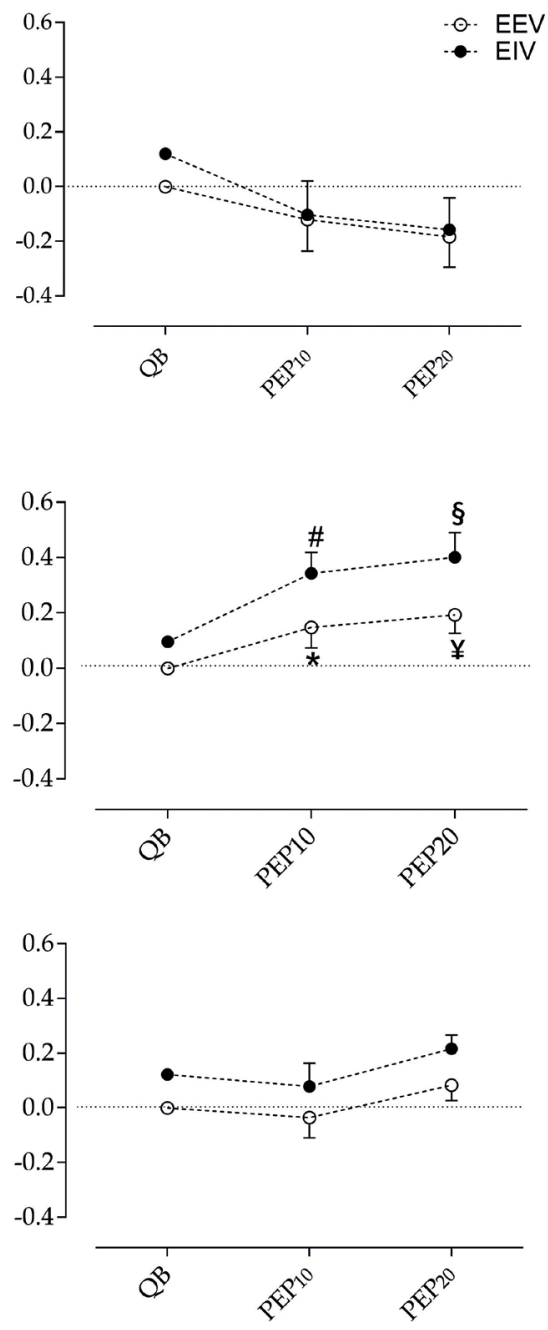

Figure 3. Operating total and compartmental chest wall volumes during different intensities of PEP 
When considering total and compartmental EIVs, intergroup analysis showed significant difference between $\mathrm{CF}$ and controls only at $\mathrm{PEP}_{20}$ for abdomen compartment ( $p>0.01$, Figure 4).



\section{○ Control Group}

- Cystic Fibrosis

Figure 4. End-inspiratory volume (EIV) in abdomen during different intensities of PEP

Values represent mean \pm deviation. QB: Quiet breathing; PEP.: Positive expiratory pressure 10 $\mathrm{cmH}_{2} \mathrm{O} ; \mathrm{PEP}_{20}$ : Positive expiratory pressure $20 \mathrm{cmH}_{2} \mathrm{O}$. ${ }^{*} p>0.01$ (two-way ANOVA). Bonferroni's post hoc between groups

\section{DISCUSSION}

Results showed that chest wall tidal volume increased during the use of PEP in comparison to quiet breathing. Moreover, the increase was significantly higher in controls compared to $\mathrm{CF}$ during $\mathrm{PEP}_{20}$. We also found that, compared to controls, children with $\mathrm{CF}$ are characterized by a more rapid and shallow breathing pattern, both during spontaneous quiet breathing at rest and during the use of PEP, as showed in Figure 2A. In addition, we have shown that minute ventilation increases in $\mathrm{CF}$ children during the use of PEP due to an increase of tidal volume. End-expiratory volume also increases compared to quiet breathing.

$\mathrm{PEP}$ is one of the most common airway clearance techniques used in different countries, such as Canada ${ }^{5}$. A recent study with 6,372 $\mathrm{CF}$ patients performed in the United Kingdom, showed that PEP was the third most popular technique used to manage patients' conditions ${ }^{28}$. Despite its wide dissemination and use, little is known about its effects in ventilation. This feature is not related only to PEP, but all airway clearance techniques. The lack of knowledge about the physiological responses of airway clearance techniques was observed in the conclusion of five Cochrane systematic reviews that were inconclusive regarding the best airway clearance technique for $\mathrm{CF}$ patients 5 .

The acute effects of PEP have been previously studied in the literature. However, in the previous studies the possible dynamic changes in ventilation and breathing pattern were not assessed. Van Winden et al. (1998) studied the effects of flutter and PEP mask in symptoms and lung function in $22 \mathrm{CF}$ patients ${ }^{29}$. The authors did not find any significant changes in lung function parameters after a single session or 2 weeks of PEP or flutter use. A recent study, by McIlwaine et al. 30, analyzed long-term efficacy of high frequency chest wall oscillation (HFCWO) in comparison to theraPEP in patients with $\mathrm{CF}^{30}$. The primary outcome was the number of pulmonary exacerbations. The authors found no significant difference in quality of life and lung function between the groups. PEP showed to be more efficient in terms of time of use and number of exacerbations (1.14 for PEP vs 2.0 for HFCWO). A great number of $\mathrm{CF}$ studies aim to compare airway clearance techniques. On the other hand, we consider that is more important to first understand the mechanisms and how patients respond to each technique, in this case, PEP.

To our knowledge, this is the first study that evaluated the acute effects of PEP in the volumes of chest wall and its compartments in CF children. For this propose, we have used Optoelectronic Plethysmography, which provides continuous dynamic measurements of volume variations of the chest wall, divided into compartments ${ }^{17}$. Our results showed a rapid and shallow breathing pattern at rest and during use of different intensities of PEP in children with CF. Even though minute ventilation was similar between groups, $\mathrm{CF}$ patients showed less efficient breathing patterns compared to controls, as observed by the increased respiratory rate (at rest and during PEP use) and a decreased tidal volume during $\mathrm{PEP}$ use.

In fact, the use of PEP in Cystic Fibrosis and controls showed an increase in minute ventilation, compared to quiet breathing. The mechanism that leads to this increase, however, differs between groups, at least at the highest level of PEP considered in the study. While in controls the increase in ventilation was due to a significant increase of tidal volume when both $\mathrm{PEP}_{10}$ and $\mathrm{PEP}_{20}$, were applied, in CF subjects the tidal volume significantly increased only during the application of $\mathrm{PEP}_{10}$, while at $\mathrm{PEP}_{20}$ an increase of respiratory rate was observed. A clinical implication of 
our findings is, therefore, that high levels of PEP should not be used in children with $\mathrm{CF}$, to avoid overloading respiratory muscles to overcome the load imposed by the use of PEP.

There is still a lack of studies showing respiratory strength impairment in subjects with CF in the literature. Published data in the same topic are also controversial, however, we may speculate that individuals with $\mathrm{CF}$ show difficulty in overcoming a pressure load of 20 $\mathrm{cmH}_{2} \mathrm{O}$ due to reduction of the strength of expiratory muscles, as shown by the lower values of maximal expiratory pressure (MEP: $83.1 \pm 25.9$ vs. $109 \pm 21.5$ for $\mathrm{CF}$ and control groups, respectively), compared to controls, found in this study.

We may hypothesize that the increase in endexpiratory volume observed during PEP may be beneficial, particularly in those children in which the restrictive pattern is prevalent. On the other hand, in those children in which the obstructive pattern is prevalent, the EEV increase induced by PEP could not be clinically interesting as these subjects present pulmonary hyperinflation due to air trapping in the lungs, which was maintained.

We believe that the main limitation of our study is the small sample of participants and extrapolation of the results should be done carefully. However, CF is not a common lung disease, therefore, its low prevalence makes the recruitment of individuals even more limited.

\section{CONCLUSION}

In conclusion, different levels of PEP induce an increase of chest wall volumes in CF children with different mechanisms compared to controls. Even with the improvement caused by PEP, CF children still show shallow breathing characteristics. PEP levels above $10 \mathrm{~cm} \mathrm{H}_{2} \mathrm{O}$ should be used with caution in CF children.

\section{REFERENCES}

1. Ramsey BW. Management of pulmonary disease in patients with cystic fibrosis. N Engl J Med. 1996;335(3):179-88. doi: 10.1056/NEJM199607183350307.

2. Knowles MR, Stutts MJ, Yankaskas JR, Gatzy JT, Boucher $\mathrm{RC}$ Jr. Abnormal respiratory epithelial ion transport in cystic fibrosis. Clin Chest Med. 1986;7(2):285-97.

3. Phelan PD, Olinski A, Robertson CF. Respiratory ilness in children. Oxford: Blackwell; 1994.
4. Lannefors L, Button BM, Mcllwaine M. Physiotherapy in infants and young children with cystic fibrosis: current practice and future developments. J R Soc Med [Internet]. 2004 [acesso em 17 ago. 2017];97(Suppl. 44):S8-25. Disponível em: https:// goo.gl/GZ63FG

5. Bradley JM, Moran FM, Elborn JS. Evidence for physical therapies (airway clearance and physical training) in cystic fibrosis: an overview of five Cochrane systematic reviews. Respir Med. 2006;100(2):191-201. doi: 10.1016/j. rmed.2005.11.028.

6. Pisi G, Chetta A. Airway clearance therapy in cystic fibrosis patients. Acta Biomed [Internet]. 2009 [acesso em 17 ago. 2017];80(2):102-6. Disponível em: https://goo.gl/baEz1s

7. Main E, Prasad A, Schans C. Conventional chest physiotherapy compared to other airway clearance techniques for cystic fibrosis. Cochrane Database Syst Rev. 2005;(1):CD002011. doi: 10.1002/14651858.

8. Warnock L, Gates A, van der Schans CP. Chest physiotherapy compared to no chest physiotherapy for cystic fibrosis. Cochrane Database Syst Rev. 2013;(2):CD001401. doi: 10.1002/14651858.CD001401.pub2.

9. Prasad SA, Tannenbaum E-L, Mikelsons, C. Physiotherapy in cystic fibrosis. J R Soc Med [Internet]. 2000 [acesso em 17 ago. 2017];93(Suppl. 38):27-38. Disponível em: https://goo. gl/V7TfVo

10. Laube BL, Geller DE, Lin TC, Dalby RN, Diener-West M, Zeitlin PL. Positive expiratory pressure changes aerosol distribution in patients with cystic fibrosis. Respir Care [Internet]. 2005 [acesso em 17 ago. 2017];50(11):1438-44. Disponível em: https://goo.gl/cFtL78

11. Hunter JM, Sperry EE, Ravilly S, Colin AA. Thoracoabdominal asynchrony and ratio of time to peak tidal expiratory flow over total expiratory time in adolescents with cystic fibrosis. Pediatr Pulmonol. 1999;28(3):199-204.

12. Allen JL, Wolfson MR, McDowell K, Shaffer TH. Thoracoabdominal asynchrony in infants with airflow obstruction. Am Rev Respir Dis. 1990;141(2):337-42. doi: 10.1164/ajrccm/141.2.337.

13. Mayer OH, Clayton RG Sr, Jawad AF, McDonough JM, Allen $\mathrm{JL}$. Respiratory inductance plethysmography in healthy 3- to 5-year-old children. Chest 2003;124(5): 1812-9. doi: 10.1378/ chest.124.5.1812.

14. Reber A, Geiduschek JM, Bobbià SA, Bruppacher HR, Frei FJ. Effect of continuous positive airway pressure on the measurement of thoracoabdominal asynchrony and minute ventilation in children anesthetized with sevoflurane and nitrous oxide. Chest. 2002;122(2):473-8. doi: 10.1378/ chest.122.2.473.

15. Capria ME, D’Nedri C, De Vito EL. Relationship between Hoover sign, functional and variables, and curvature radius in patients with obstructive pulmonary disease. Medicina (B Aires). 2003;63(5):369-76.

16. Garcia-Pachon E, Padilla-Navas I. Frequency of Hoover's sign in stable patients with chronic obstructive pulmonary disease. Int J Clin Pract. 2006;60(5):514-7. doi: 10.1111/j.1368-5031.2006.00850.x.

17. Aliverti A, Pedotti A. Opto-electronic plethysmography. Monaldi Arch Chest Dis. 2003;59(1):12-6. 
18. World Health Organization. Declaration of Helsinki: ethical principals for research involving human subjects. Bull World Health Organ [Internet]. 2001 [acesso em 17 ago. 2017];79(4):373-4. Disponível em: https://goo.gl/4rCKZp

19. World Health Organization. Child growth standards based on lenght/height, weight and age. Acta Paediatr. 2007;95:7685. doi: 10.1111/j.1651-2227.2006.tb02378.x.

20. Miller MR, Hankinson J, Brusasco V, Burgos F, Casaburi R, Coates A, et al. Standardisation of spirometry. Eur Respir J. 2005;26(2):319-38. doi: 10.1183/09031936.05.00034805.

21. Mallozi MC. Valores de referência para espirometria em crianças e adolescentes, calculados a partir de uma amostra da cidade de São Paulo [Tese]. São Paulo: Escola Paulista de Medicina; 1995.

22. American Thoracic Society, European Respiratory Society. ATS/ERS Statement on respiratory muscle testing. Am J Respir Crit Care Med. 2002;166(4):518-624.. doi: 10.1164/ rccm.166.4.518.

23. Lanza FC, Santos MLM, Selman JPR, Silva JC, Marcolin N, Santos J, et al. Reference equation for respiratory pressures in pediatric population: a multicenter study. PLoS One. 2015;10(8):e0135662. doi: 10.1371/journal.pone.0135662.

24. Cala SJ, Kenyon CM, Ferrigno G, Carnevali P, Aliverti A, Pedotti $A$, et al. Chest wall and lung volume estimation by optical reflectance motion analysis. J Appl Physiol [Internet].
1996 [acesso em 17 ago. 2017];81(6):2680-9. Disponível em: https://goo.gl/CyGkv3

25. Aliverti A, Cala SJ, Duranti R, Ferrigno G, Kenyon CM, Pedotti A, et al. Human respiratory muscle actions and control during exercise. J Appl Physiol [Internet]. 1997 [acesso em 17 ago. 2017];83(4):1256-69. Disponível em: https://goo.gl/HW7vgc

26. Aliverti A, Uva B, Laviola M, Bovio D, Lo Mauro A, Tarperi $\mathrm{C}$, et al. Concomitant ventilatory and circulatory functions of the diaphragm and abdominal muscles. J App Physiol. 2010;109(5):1432-40. doi: 10.1152/japplphysiol.00576.2010.

27. Cohen J. Statistical power analysis for the behavioral sciences. 2. ed. Hillsdale: Lawrence Erbaum; 1988.

28. Hoo ZH, Daniels T, Wildman MJ, Teare MD, Bradley JM. Airway clearance techniques used by people with cystic fibrosis in the UK. Physiotherapy. 2015;101(4):340-8. doi: 10.1016/j. physio.2015.01.008.

29. van Winden CMQ, Visser A, Hop W, Sterk PJ, Beckers S, Jongste JC. Effects of flutter and PEP mask physiotherapy on symptoms and lung function in children with cystic fibrosis. Eur Respir J. 1998;12(1):143-7. doi: 10.1183/09031936.98.12010143.

30. Mcllwaine MP, Alarie N, Davidson GF, Lands LC, Ratjen F, Milner R, et al. Long-term multicentre randomised controlled study of high frequency chest wall oscillation versus positive expiratory pressure mask in cystic fibrosis. Thorax. 2013;68(8):746-51. doi: 10.1136/thoraxjnl-2012-202915. 